Relations industrielles

Industrial Relations

\title{
Fragiles compétences, coordonné par Sophie Bretesché et Cathy Krohmer, Paris : Presses des Mines, 2010, 198 p., ISBN : 978-2-911256-30-1.
}

\section{Amélie Bernier}

Volume 68, numéro 2, printemps 2013

URI : https://id.erudit.org/iderudit/1016327ar

DOI : https://doi.org/10.7202/1016327ar

Aller au sommaire du numéro

Éditeur(s)

Département des relations industrielles de l’Université Laval

ISSN

0034-379X (imprimé)

1703-8138 (numérique)

Découvrir la revue

Citer ce compte rendu

Bernier, A. (2013). Compte rendu de [Fragiles compétences, coordonné par Sophie Bretesché et Cathy Krohmer, Paris : Presses des Mines, 2010, 198 p., ISBN : 978-2-911256-30-1.] Relations industrielles / Industrial Relations, 68(2), 348-350. https://doi.org/10.7202/1016327ar

Tous droits réservés (C Département des relations industrielles de l’Université Laval, 2013
Ce document est protégé par la loi sur le droit d'auteur. L'utilisation des services d'Érudit (y compris la reproduction) est assujettie à sa politique d'utilisation que vous pouvez consulter en ligne.

https://apropos.erudit.org/fr/usagers/politique-dutilisation/ 
and developing them further both analytically and conceptually. There is a high standard maintained throughout the handbook with chapters written by 48 authors from across the world. This allows discussion to move away from the traditional US-centric nature of the discipline and gives the book a truly international flavour. The range of scholars from $\mathrm{PhD}$ candidates to established Professors makes for an impressive collection, which should be widely read by Human Resource Management and International Business academics and practitioners alike.

\section{Andy Hodder}

University of Birmingham

\section{Fragiles compétences}

coordonné par Sophie Bretesché et Cathy Krohmer, Paris : Presses des Mines, 2010, 198 p., ISBN : 978-2-911256-30-1.

Dès les premières pages, le lecteur est intéressé par le retour que font Bretesché et Krohmer sur le discours construit ou plutôt à déconstruire sur la notion de compétence qui renvoie à l'employabilité, à la compétitivité et à la performance.

À travers le regard de chercheurs en sociologie et en gestion, cet ouvrage regroupe neuf études de cas permettant d'éclairer la question des démarches de compétences en fonction de caractéristiques organisationnelles, stratégiques et individuelles. Les auteurs tentent de montrer, par des trajectoires individuelles et collectives incarnées dans des cas d'entreprises, comment les mutations du travail et de l'organisation permettent d'appréhender les contextes particuliers où la question de la compétence se pose. Le présent ouvrage est le fruit d'un travail empirique conduit par une équipe de dix chercheurs auprès d'acteurs de neuf entreprises différentes de la région Pays de la Loire en France. Les entreprises retenues, de toutes natures (industries du textile, de la construction, des services, de l'électronique, etc.) et de toutes tailles (100 à 950 salariés), s'inscrivent dans une démarche compétence dont l'élaboration d'un référentiel et l'évaluation des salariés sont les modalités tangibles ou structurées. Les auteurs organisent l'ouvrage Fragiles compétences autour de quatre cas de " figure » permettant une lecture transversale des démarches de compétences et des nouvelles règles de gestion et de travail au sein d'entreprises. Une synthèse est présentée au tout début de chacune des quatre catégories-types, permettant de contextualiser les expériences vécues et les points de vue des acteurs et de faire ressortir les forces et les faiblesses des démarches de compétences.

Sous le premier cas de figure, "Re-qualifier le travail », deux études de cas permettent de présenter les nouvelles qualités et compétences attendues des salariés et les nouvelles exigences et rôles professionnels que doivent maîtriser ceux-ci. Les deux études de cas, I'une dans le secteur du textile (Modeluxe) et I'autre dans le secteur de I'habitat social (Logemer), partagent trois principales caractéristiques communes, à savoir: l'absence de négociation collective, le passage d'un modèle productif à un modèle caractérisé par la flexibilisation où les changements sont continuels et imposés par le client, ainsi que la difficile reconnaissance des compétences en dehors de l'industrie. Le cas d'entreprise Modeluxe est intéressant puisqu'il montre le passage d'une organisation du travail structurée de façon tayloriste à une réorganisation en fonction de groupes autonomes de travail, forçant les salariés à se responsabiliser collectivement autour d'objectifs de qualité. Cette étude de cas illustre une démarche compétence non alignée avec les nouveaux processus de travail puisque l'évaluation porte sur les compétences individuelles et non sur la reconnaissance des compétences collectives. L'étude de cas Logemer illustre davantage, quant à elle, les effets de la démarche compétence sur la logique de métier.

La deuxième partie de l'ouvrage regroupe trois études de cas du secteur de la fabrica- 
tion (menuiserie, automobile, électronique) montrant comment les compétences individuelles doivent s'adapter et répondre aux besoins d'un alignement stratégique avec les objectifs organisationnels. Sous le chapeau « Optimiser les ressources humaines », ces trois études de cas (Fenêtre, Equip et Silicone) font ressortir clairement trois éléments : I'importance de I'alignement des compétences individuelles avec des indicateurs de performance organisationnelle, la forte concurrence au sein des secteurs d'activités et l'instrumentalisation accrue des compétences par la formalisation des processus de production. Le portrait de ces études de cas amène à questionner la pérennité de la démarche compétence dans un contexte changeant, les perspectives d'évolution de la démarche et le concept même de compétence.

Le troisième cas de figure, "Accompagner le projet d'entreprise », regroupe deux études de cas où l'instrumentalisation est délaissée au profit d'une démarche participative et d'une capacité d'adaptation permettant aux compétences individuelles de suivre les mutations et l'évolution de l'entreprise. D'abord, il y a Batiscop, une PME de l'industrie de la construction où la démarche des compétences en fait une entreprise apprenante. La démarche compétence semble ici donner un sens au travail et est favorisée par l'accompagnement des employés. Les situations de travail sont rapportées comme étant des occasions de formation, d'apprentissage et de transfert bénéfiques à tous les salariés. Ensuite, il y a Gruescop, une entreprise désignée comme un équipementier où la démarche compétence repose sur l'enjeu de la transmission des savoir-faire dans un contexte de vieillissement de la main-d'œuvre. Cette entreprise illustre aussi une démarche compétence structurée au sein de laquelle on peut lier les activités de formation à la transformation même des métiers et à une logique de professionnalisation. On peut ajouter qu'autant pour Batiscop que pour
Gruescop, la question des compétences des ressources humaines représente une réflexion globale et collective où les salariés sont au cœur même de la démarche, où I'on distingue facilement des modalités non structurées liées au transfert des compétences et où les entreprises sont accompagnées par un réseau d'acteurs externes.

Enfin, la quatrième section de l'ouvrage présente deux études de cas (ToutesGraines et Micro-Contrôle) regroupées sous la figure «Articuler le global et le local », où I'on tente de montrer comment les compétences s'articulent et se transforment en fonction des strates organisationnelles. Ces études de cas rendent compte de l'hétérogénéité des raisons et des finalités de la mise en œuvre d'une démarche compétence où I'on valorise les compétences individuelles. Dans Toutes-Graines, la démarche compétence repose sur la formalisation des outils, de l'identification des compétences à leur évaluation. Les salariés doivent " faire la preuve » de leurs compétences, ce qui signifie que la reconnaissance des compétences exige de l'employé un dépassement continuel des exigences. Le cas de Micro-Contrôle, pour sa part, illustre spécifiquement une démarche visant à répondre aux besoins de créer de nouvelles possibilités de reconnaissance des compétences pour les ingénieurs. Par ailleurs, comparativement aux autres études de cas dont il est question dans cet ouvrage, les entreprises regroupées dans cette section présentent des sites locaux de production comptant pour moins de $5 \%$ des effectifs globaux des deux entreprises. La démarche compétences au cœur de ces deux études de cas découle d'un besoin continu d'adaptation forçant les employés à intégrer rapidement et constamment de nouvelles compétences et connaissances à des situations de travail vécues et auparavant bien maitrisées.

Les qualités de l'ouvrage sont donc nombreuses. Ce livre offre une lecture rafraîchissante des enjeux des démarches compétence dans différents secteurs 
d'activités en montrant simplement mais efficacement le caractère multiforme de ces démarches à travers quatre catégoriestypes. Cet ouvrage pourra tout aussi bien être une référence utile pour les universitaires que pour les partenaires sociaux intéressés à documenter leurs réflexions sur les compétences situées et les thématiques connexes aux démarches compétences: transfert, instrumentalisation, reconnaissance et évaluation.

Pour conclure, cet ouvrage mérite qu'on s'y intéresse, d'abord pour situer nos propres compétences par rapport à des cas vécus, mais aussi pour rendre compte du sens que I'on donne aux compétences, à la place grandissante de leur instrumentalisation et de la formalisation par rapport aux situations rapportées, vécues et documentées qui montrent, en fait, l'importance des dimensions non formelles et informelles.

\section{Amélie Bernier}

TÉLUQ I Université du Québec

\section{Valuing Care Work: Comparative Perspectives}

edited by Cecilia Benoit and Helga Hallgrimsdóttir, Toronto: University of Toronto Press, 2011, 292 pp., ISBN: 978-14426-1092-7.

Care work is a broad concept that covers all tasks that involve care activities undertaken in the service of others whether this is done for pay or without remuneration. In recent years this work has become a topic that has attracted a growing body of academic analysis and the editors and 25 contributors to this work are to be applauded for adding to this effort. Valuing Care Work is a readable text which spans a broad range of topics related to both paid and unpaid caring. Benoit and Hallgrimsdóttir bring together a body of contributors from Canada, Finland and Iceland to examine care work which they present in a text that offers insightful commentary that on occasion is truly excellent. The range of topics addressed is impressive and in the case of this reader certainly aroused interest. Topics explored include comparative analysis across social and spatial contexts, paid care work in formal organizations and in intimate and community settings, unpaid care work in intimate settings and economic organizations, and policy implications with all contributions being situated in an environment conditioned by neo-liberalism. The highlight of the text is Phillips, Casey and Leischner's chapter that discusses workers who are employed in non-profit organizations that care for the needs of sex workers. This contribution is a stand-out for the way in which it clarifies the stressors and concerns of the workers studied and recognizes that these workers can and do provide important care but remain human beings who are torn and compromised by the situation in which they work.

The overarching argument and purpose of the editors is to show that "the more welfare states base their social policies on the principle of caring, the closer they come to championing gender equality in all sectors of society, one where men's involvement in caring work is championed, where there is equal balance between paid and unpaid work for both women and men, with both sharing opportunities and responsibilities" (p. 10). This is an objective that is to be applauded and the text makes a contribution that may encourage some readers to make greater effort to carry this goal forward. But while the text is successful in challenging the assumption that care work is straightforward sadly the value of the contribution made by the work is somewhat undermined by a failure to adequately specify what care work entails and by a perspective that values women's care work but, devalues the caring labour undertaken by men.

When explaining what constitutes care work the editors suggest that most of the activities embraced by this notion "are in some way or other connected with the 